\section{UCDNN}

LIBRARY
University of Connecticut OpenCommons@UConn

Faculty Articles and Papers

School of Law

2009

\title{
The Invention of Legal Primitivism
}

Steven Wilf

University of Connecticut School of Law

Follow this and additional works at: https://opencommons.uconn.edu/law_papers

Part of the Law and Society Commons, Legal History Commons, and the Public Law and Legal Theory Commons

\section{Recommended Citation}

Wilf, Steven, "The Invention of Legal Primitivism" (2009). Faculty Articles and Papers. 19.

https://opencommons.uconn.edu/law_papers/19 


\section{HEINONLINE}

Citation: 10 Theoretical Inq. L. 4852009

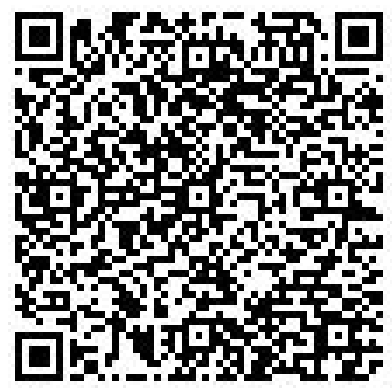

Content downloaded/printed from

HeinOnline (http://heinonline.org)

Mon Aug 15 17:35:14 2016

-- Your use of this HeinOnline PDF indicates your acceptance of HeinOnline's Terms and Conditions of the license agreement available at http://heinonline.org/HOL/License

-- The search text of this PDF is generated from uncorrected OCR text.

-- To obtain permission to use this article beyond the scope of your HeinOnline license, please use:

https://www.copyright.com/ccc/basicSearch.do? \&operation $=$ go\&search Type $=0$ \&lastSearch =simple\&all=on\&titleOrStdNo=1565-1509 


\title{
The Invention of Legal Primitivism
}

\begin{abstract}
Steven Wilf
This Article addresses a different sort of legal transplant - one in which outside legal doctrines are imported in order to be cabined, treated as normative counterpoints, and identified as the legal other. Legal primitivism is a kind of anti-transplant. It heightens the persistent differences between a dominant legal system and its understanding of primitive rules. An often ignored legal literature depicting legal primitivism emerged in the second half of the nineteenth century and in the early twentieth century. Mapping the differences between America's modern legal system and its antecedents, this immense literature, which included works by Oliver Wendell Holmes, James Coolidge Carter, and John Henry Wigmore, described an archaic legalism which sometimes belonged to tribal societies, and sometimes was simply conjured out of thin air. Exploring the project of constructing geographies of legal knowledge assists in our understanding of American law in a period of significant change. What elements of primitive law were valorized? Which were seen as archaic or repugnant? And what was the purpose of constructing a legal doppelgänger? By examining these cultural negotiations, and holding legal primitivism up as a mirror to modern law, it is possible to uncover the anxieties of legal modernism.
\end{abstract}

\section{INTRODUCTION}

This is an essay about the origins of legal modernism - and precious little will be said about them. America's received historical narrative about legal modernism has been repeated so often as to have become comfortably

* I would like to thank Anne Dailey, Ron Harris, Morton Horwitz, Amalia Kessler, Roy Kreitner, Pnina Lahav, Assaf Likhovski, Jeremy Paul, Richard Ross, Susan Schmeiser, Yoram Shachar, Christopher Tomlins, and Carol Weisbrod. I am grateful to the Institute for Advanced Studies at the Hebrew University of Jerusalem, which provided such a superb environment for the writing of this Article. 
unexamined. Modernism is the United States Supreme Court's response to the high-water mark of formalism denoted by Lochner v. New York. It is the trumping of doctrinal and black letter approaches to cases by bands of legal realists at Columbia and Yale law schools. Modernism is the undoing of the shackles of formal legal analysis, the burying of the dead hand of the past, the recognition that law is largely functional - and therefore the moment when autonomous judges, scholars, and public-minded attorneys reconstruct law in the image of society. ${ }^{\prime}$ It is a forward-looking march to the future. Since no credible story of transformation can be so sudden, there are transition figures in this tale such as Roscoe Pound and Wesley Hohfeld. Oliver Wendell Holmes is a favorite, and it has become something of a cottage industry to identify his conversion on the road to Damascus, which somehow also turns out to be the Path of the Law. ${ }^{2}$

But for all the agreement about the genealogical origins of legal modernism, the legacy of this movement remains contested. For law and society scholars, modernism means empirical social science, objective understandings of norms, and a pragmatic, functional, and antifoundationalist approach to lawmaking. ${ }^{3}$ Critical legal studies scholars, too, claim to be the heirs to legal modernism. Evoking the analogy of cultural modernism in art and literature to explain its legal embodiment, modernism, David Luban suggests, is "provocative, creates a sudden sense of loss through disenchantment, and sows uncertainty. It involves line-crossing like a Jackson Pollock painting or a John Cage piano piece." Critical legal studies, he argues,

1 Morton J. Horwitz, The Transformation of American Law 1870-1960: The CRISIS OF LEGAL ORTHODOXY (1992). My chronology in this essay roughly follows that used in WILLIAM M. WIECEK, THE LOST WORLD OF CLASSICAL LEGAL THOUGHT: LAW AND IDEOLOGY IN AMERICA 1886-1937 (1998). As here employed, the modernist enterprise includes both the construction of a jurisprudence with claims to being apolitical, objective, and quasi-neutral through its reliance upon a dense, and increasingly systematized, doctrine, and proto-realist and realist critiques of what has been called legal orthodoxy.

2 See especially Robert W. Gordon, The Legacy of Oliver Wendell Holmes, JR. (1992); SteVEn J. BuRTON, The PATH OF THE LAW ANd Its Influence (2000); Neil Duxbury, The Birth of Legal Realism and the Myth of Justice Holmes, 20 ANGLO-AM. L. REV. 81 (1991). For the situating of Holmes' psychological posture away from his role as a legal realist precursor, see Anne Dailey, Holmes and the Romantic Mind, 48 DukE L.J. 429 (1998). Thomas Grey, Langdell's Orthodoxy, 45 U. PITT. L. REV. 1, 5 (1983) points out that for at least a century there has been a steady polemic against "mechanical jurisprudence."

3 RICHARD A. POSNER, FRONTIERS OF LEGAL THEORY 31-61 (2001). On the legal realist project of enlisting social science tools, see JOHN HENRY SCHLEGEL, AMERICAN LEGAL REALISM AND EMPIRICAL SOCIAL SCIENCE (1995). 
is legal modernism because it makes people angry; it leaves a hunger unsatisfied (e.g., for "serious" doctrinal analysis or practicable alternative proposals); it thrives in an atmosphere of polemic and manifesto and autocommentary; its characteristic mode of failure is quackery rather than mediocrity; and the members of the ... movement themselves don't know - I say can't know — when they are worth taking seriously. ${ }^{4}$

Critical legal studies is avant-garde, an oppositional discourse. ${ }^{5}$

Is legal modernism about empirical certainty or critical indeterminacy? This is the core question posed by the jostling of law and economics and critical legal studies over the relic - or perhaps we should say remains - of legal modernism. This debate has become somewhat stale. Most participants, as generally happens with long-standing disagreements, have become increasingly convinced of the correctness of their stance. The easiest approach is to say there are many modernisms - which is certainly true. However, I want to take a new tack, and not look at our own conceptions of the modern - but, instead, to probe the experience of legal modernism for its participants, and to see how contemporaries responded to the systematization of legal formalism and legal realism.

This essay does so by holding a mirror up to legal modernism. It focuses on a vast, almost completely neglected Anglo-American literature dealing with legal primitivism that emerged in the period between the 1861 publication of Henry Sumner Maine's Ancient Law and Karl Llewellyn's and E. Adamson Hoebel's The Cheyenne Way, which appeared in $1941 .^{6}$ This period represents the apotheosis of legal primitivism in America. Although Maine was British, his work circulated so widely in the United States that it marked the beginnings of an American cultural conversation that extended over the next eighty years. Llewellyn and Hoebel addressed this conversation. As we shall see, they also shifted the ground of legal primitivism away from a tradition of

4 DAVID LUBAN, LEGAL MODERNISM 51-92 (1994).

5 David Trubek, Where the Action Is: Critical Legal Studies and Empiricism, 36 STAN. L. REV. 575 (1984) identifies critical legal studies as founding its critique upon indeterminacy, antiformalism, contradiction, and marginality. According to Mark Tushnet, it challenges the formalism inherent in liberal political theory. Mark Tushnet, Perspectives on Critical Legal Studies: Introduction, 52 GEO. WASH. L. REV. 239, 239-40 (1984).

6 In terms of periodization, this time frame encompasses the period of greatest influence for primitive law upon legal studies. Of course, modern anthropological investigations into the primitive would continue with seminal work on the primitive mind by Franz Boas, Lucien Lévy-Bruhl, Malinowski, and others. 
historical jurisprudence and towards professional anthropological research. Most of the important figures on both sides of the Atlantic in the formative generation of the 1860s and 1870s that dealt with the primitive mind had been trained in law, including Johann Jakob Bachofen, Josef Köhler, Henry Sumner Maine, J.M. McLennan, and Lewis Henry Morgan, and their influence pointed examinations of the primitive mind in a notably law-centered direction. ${ }^{7}$ The genre of legal primitivism includes the works of early sociologists and political theorists such as Darwinian philosopher Herbert Spencer, prominent Yale sociologist and social commentator William Graham Sumner, and anxious and vexatious social conservative Brooks Adams, as well as the production of academic and practicing lawyers, James Coolidge Carter, Guy Carleton Lee, and Henry Wilson Scott.

Guy Carleton Lee defined the role of such historical jurisprudence as holding "fast to the thread which binds together the modern and primitive conceptions of law, and seek[ing] to trace through all the tangled mazes which separate the two, the line of connection between them. ${ }^{88}$ In the midst of codifying modern rules of evidence, John Henry Wigmore, a Progressive era reformer and Dean at Northwestern Law School, assembled a multivolume casebook, Primitive and Ancient Legal Institutions, in order to facilitate this subject being added to the law school curriculum. ${ }^{9}$ Although for the most part ignored in current legal historical literature, ideas about legal primitivism nevertheless circulated widely in their day. They were the subject of high

7 Among their works are JoHANN JAKOB BACHOFEN, DAS MuTtERRECHT (Basel, Benno Schwabe 1891) (1861); Josef Köhler, Zur Urgeschichte der Ehe: Totemismus, Grupenehe, Mutterrecht, 12 ZEITSCHRIFT FÜR VERGLEICHENDE Rechtswissenschaft 187 (1897); J.M. Mclennan, Primitive Marriage: An INQUIRY INTO THE ORIGIN OF THE Form OF CAPTURE IN MARRIAGE CEREMONIES (Edinburgh, A \& C Black 1865); and LewiS H. MORGAN, ANCIENT SoCIETY: RESEARCHES IN THE Lines of Human Progress from Savagery Through BARBARISM TO CivilizaTION (New York, H. Holt \& Co. 1877). On German legal primitivism, see Rüdiger Schott, Main Trends in German Ethnological Jurisprudence and Legal Ethnology, in 1 FOLK LAW: ESSAYS IN THE THEORY AND PRACTICE OF LEX NON SCRIPTA 201 (Alison Dundes Renteln \& Alan Dundes eds., 1994). While this literature includes strong German and French sources (such as writings by Émile Durkheim and Marcel Mauss), we will focus on American sources with occasional reference to a broader Anglo-American tradition of legal primitivism.

8 GuY Carleton LEE, Historical JURISPRUdENCE: AN INTRODUCTION TO THE SYSTEMATIC STUDY OF THE DEVELOPMENT OF LAW 6 (1900).

9 Albert KoCOUREK \& John H. Wigmore, Primitive AND ANCIENT Legal INSTITUTIONS (1915). It is important to ask why the rendering of the savage was so persuasive. For a similar approach, see Marilyn Strathern, Out of Context: The Persuasive Fictions of Anthropology, 28 CURRENT ANTHROPOLOGY 251 (1987). 
mandarin social theory debates; the work of legal historians, ethnologists, and pseudo-scientists; and seen as a suitable subject matter for law students and the practicing bar. At an American Bar Association meeting in 1897, one enthusiastic supporter of legal primitivism urged pushing back the timeline from law to custom to social need. It was no longer enough simply to read Coke and Blackstone to understand the origins of the Anglo-American legal system. "The true student of English law," he argued, "must stand at Stonehenge."10

Legal primitivism was a foil, a counterpoint, a projection, and an alter ego of legal modernism. Primitivism evokes expression of the "untamed self." ${ }^{11}$ Primitives "do not think or analyze their culture," wrote Alexander Goldenweiser, "they live it." ${ }^{12}$ The primitive mind "is more susceptible to emotions." ${ }^{13}$ If legal formalism might be described as analytic and systematic, and legal realism as self-conscious and programmatic, legal primitivism was portrayed as almost childlike. The savage served as doppelgänger of the modern. In a symbolic binary code of opposites, it was the legal other. Legal modernism should be seen as much as a cultural gesture as it was a series of moves to reform legislative and judicial rules. ${ }^{14}$ Legal primitivism was its counter-gesture.

Primitivism, too, had its cultural and psychological value. It would be a

10 Henry E. Davis, Primitive Legal Conceptions in Relation to Modern Law, in REPORT OF THE TwENTIETH ANNUAL MEETING of the AMERICAN BAR Association 469 (Philadelphia, Dando 1897).

11 Marianna Torgovnick, Gone Primitive: Savage Intellects, Modern Lives 8 (1990). Primitivism suggests both origins and the uncivilized, and, as we shall see, both of these meanings permeated the legal primitivism project. Primitivism has different valences depending upon the genre where it develops as a concept - art, anthropology, literature - and I will allow the legal sources referenced in this essay to speak for themselves. See SUSAN HILLER, THE MYTH OF PRIMITIVISM: PERSPECTIVES ON ART 55-57 (1991) for a definition of primitivism for painting and drawing. For a different reading of modern and savage in a legal context, see PETER FITZPATRICK, MODERNISM AND THE GROUNDS OF LAW 39-63 (2001). The term primitive has been seen as disparaging, and therefore has fallen into disfavor among many anthropologists. For an early critique, see Sol Tax, "Primitive" Peoples, 1 CURRENT ANTHROPOLOGY 441 (1960).

12 Alexander GoldenweISER, ANTHROPOLOGY: AN INTRODUCTION to PRIMITIVE CULTURE 47 (1937).

13 Jacob Henry Landman, Primitive Law, Evolution, and Sir Henry Sumner Maine, 28 MiCH. L. REV. 404, 408 (1930).

14 My idea of a gesture includes performative aspects of identifying a shift in jurisprudential approaches. In a somewhat similar sense, Neil Duxbury has written of the creation of a "mood." NEIL DuXBury, PATTERNS OF AMERICAN JURISPRUDENCE 65-71 (1995). 
mistake to dismiss legal primitivism as simply superstructural, simply an antiquarian enterprise of digging about in the rubbish heap of history. The sheer scale of the legal primitivism project suggests that this alternative universe to modernism must have served some function. It was, this essay argues, a kind of laboratory for legal thinking in the late nineteenth and early twentieth centuries. Primitive law was where legal commonalities and legal differences were negotiated. It was a discursive space to reflect upon an earlier golden age or, alternatively, to remark upon a troubling past which had been transcended; it provided space for excavating aspirational changes in law and for discarding unwanted doctrine. ${ }^{15}$ But every Gedankenexperiment in the rude and savage realm of primitivism really reflected the working out of modernist issues - what is the meaning of customary law in an increasingly systematized doctrinal landscape? How might law be more communitarian? Does vengeance have a place in a psychologically-rooted criminal jurisprudence? Within the rubric of legal primitivism lay the anxieties of the modern.

So far we have envisioned legal primitivism as the locus of legal imagination. To be sure, this will be the focus of our discussion. Many of the descriptions of legal primitivism are notable because they are speculative, fanciful, and impatiently push at the boundaries of the ordinary. But from the outset it should be made clear that the legal primitivism project included serious ethnographic investigations that would mark the beginning of legal anthropology. ${ }^{16}$ These works were comparative, empirical, and inductive. Legal thinkers attracted to primitivism, Maine, Morgan, and Wigmore lived for a certain amount of time, respectively, in India, upstate New York close to the Seneca, and Japan. Karl Llewellyn had an elective affinity for Icelandic sagas. ${ }^{17}$

15 It is difficult to know precisely how often the turn to legal primitivism valorized the past or, instead, rejected earlier norms, although my impression is that transcending earlier legal thinking outweighed borrowing. My point is that legal primitivism was a tableau, and many different approaches were taken toward this broad range of material. Legal primitivism was part of various social and aesthetic movements in the late nineteenth-century, which included primitivism in art and literature, and part of an increasingly sophisticated discourse of social criticism. For the latter, see T.J. JACKSON LEARS, NO PLACE OF GRACE: ANTIMODERNISM AND THE TRANSFORMATION OF AMERICAN CUlTURE 1880-1920 (Univ. of Chi. Press 1994) (1981).

16 See, for example, the construction of a questionnaire as a research tool. John Macdonnell, Primitive Laws and their Investigation: A Suggestion, 8 J. Soc'Y COMP. LEGIS. 104 (1907).

17 During his Indian period, Maine supported the application of Indian legal norms under the umbrella of the colonial administrative apparatus, despite the fact that many of these were considered by English contemporaries to be morally repugnant. 
Moreover, and this might be more important, legal primitivism emerged within the framework of colonialism. ${ }^{18}$ The distinction between the primitive and the modern has had its uses in sustaining patterns of domination over indigenous peoples. Edward Tylor, for example, called legal primitivism "comparative jurisprudence of the lower races." ${ }^{19}$ Cultural clichés can become technologies of power. It is my contention, nevertheless, that the fabular what I have called elsewhere a legal history of the imagination - can tell us a great deal about how real law, modern law, is constructed. ${ }^{20}$

Ironically for a field associated with evolutionary thinking, legal primitivism was a loser in the Darwinian struggle among jurisprudential doctrines in fin-de-siècle Anglo-America. It is important to retrieve this lost area of law in order to understand how legal modernism emerged. Primitivism draws the connection "between the world of modern [legal] technology and the archaic symbol-world of mythology" - to allow us to

Kenneth R. Bock, The Moral Philosophy of Sir Henry Sumner Maine, 37 J. HIST. IDEAS 147, 149-50 (1976). Morgan became fascinated with New York NativeAmerican ethnography as a young man. In Rochester, he became part of a literary club that sought to model itself on the League of the Iroquois. Alexander Spoehr, Lewis Henry Morgan and His Pacific Collaborators, 125 Proc. AM. PHIL. SoC'Y 449, 449-50 (1981). John Wigmore's interest in primitive law may have been related to his three-year stay in Japan when he worked to establish a Japanese law school on the Harvard model. Annelise Riles, Encountering Amateurism: John Henry Wigmore and the Uses of American Formalism, in RETHINKING THE MASTERS OF COMPARATIVE LAW 94 (Annelise Riles ed., 2001). Llewellyn, on the other hand, had a strong personal interest in Scandinavian literature, which may have shaped his turn to the primitive. Peter Dinunzio, Elinor Kim \& Robert Whitman, Karl N. Llewellyn: How Icelandic Saga Literature Influenced the Scholarship of an American Realist, 39 CONN. L. REV. 1923, 1950 (2007).

18 See, for example, the division of law into law which progresses and law (belonging to more primitive societies, the Chinese and Islamic countries) which does not progress - with the imputation of the West as the engine of moral change. DEWITT Clinton Allen, The Evolution of Our System of LaW (St. Louis, Continental Printing 1892). Perhaps the most important discussion of colonial discourse in American legal history is Christopher Tomlins, In a Wilderness of Tigers: Violence, the Discourse of English Colonizing, and the Refusals of American History, 4 THEORETICAL INQUIRIES L. 451 (2003); see also James Q. Whitman, Westem Legal Imperialism: Thinking About the Deep Historical Roots, 10 THEORETICAL INQUIRIES L. 305 (2009).

19 Edward B. Tylor, Researches into the EARLy History of Mankind and tHE DEVElopMENT OF CIVILIZATION 279 (Boston, Estes \& Lauriat 1878).

20 On the methodology of the legal history of the imagination, see STEVEN WILF, THE LAW BEFORE THE LAW, at vii-xii (2008). 
understand legal modernism's psychological underpinnings. ${ }^{21}$ Modernism meant dislocation, uncertainty, a sense of anomie and rootlessness, and longing. How might traces of these preoccupations - what Thomas Hardy called the "ache of modernism" — be found in legal primitivism? $?^{22}$

Towards a preliminary discussion of legal primitivism as an area of nineteenth and early twentieth-century jurisprudence, this essay constructs a rudimentary map of the landscape of legal primitivism. ${ }^{23}$ It begins by looking at Maine's project of valorizing customary law in response to codification, utilitarian reform, and Austinian positivism. Maine's display of legal primitivism soon became a cluttered natural history museum of the savage legal mind. Moreover, Maine's notion of the antiquity of ordered patriarchal familial life was soon challenged by disturbing images of female power, hyper-sexuality, and a Victorian normative world turned upside-down where women were readily transferred like an object among men. I suggest that the Darwinian turn in the second half of the nineteenth century, seeing primitive law as an evolutionary stage, may well have been an attempt to order the cluttered landscape of legal primitivism and to domesticate its savage eros by envisioning it as the beginning of an ascending ladder of norms.

But how do we explain the willingness to violate, even in the primeval past, what seem to be fundamental rules of conduct? By the early twentieth century, another transformation, the preoccupation with the transgressive, led to a focus on the social underpinnings of legalism. Legal realists turned to legal primitivism as a place where law in action could be seen unencumbered by law on the books. Finally, I conclude with some observations on the centrality of constructions of the other for legal thinking. For all its creaky imagery of the legal ethnologist donning a pith helmet and rucksack in search of savage norms, legal primitivism is a species of legal transplant which challenges our accepted notion of the appropriate ways to consider the importation of law.

21 Walter Benjamin, The ArCades Project 461 (Rolf Tiedemann ed., 1999).

22 Thomas Hardy, Tess of THE D'uRbervilles 160 (New York, Harper \& Bros. 1891).

23 The fact that legal primitivism has not previously been discussed as a modern jurisprudential enterprise suggests how arcane its subject matter seems to legal academics. There has been research drawing upon the Darwinian strand of legal primitivism, see the discussion below, and upon its contributions to the historical origins of modern anthropology. In some ways, legal primitivism fits the category of invented traditions since so many of its claims were constructed as if they were rooted in primeval history. THE INVENTION OF TRADITION (Eric Hobsbawm \& Terrence Ranger eds., 1992). 


\section{Mapping Legal Primitivism}

Explaining his turn to paleo-history, James Coolidge Carter, perhaps the leading appellate advocate of the late nineteenth century and opponent of the Field codification project, argued that "we can more easily learn the real nature of complex instrumentality, whether it be a piece of mechanism like the steam engine, or an institution like law, if we begin by studying it in its original and simplest form." ${ }^{24}$ Carter's investigation of legal primitivism was intimately related to his concerns about the over-systematization of law, especially through codification. Custom, he argued, had served early societies well. It was flexible, had at its disposal a complex arsenal of constraints, and reflected fundamental social mores. The imposition of legislative codes occurred in times of crisis. Carter has been identified as a follower of Friedrich Karl von Savigny, the German scholar who founded a school of historical jurisprudence which identified law as emanating from the organic needs of society. However, throughout Carter's work on primitivism might be seen the influence of Henry Sumner Maine's Ancient Law, which was published in 1861.

Maine, a professor at Oxford, could be called the founder of the AngloAmerican legal primitivism project, partly because Ancient Law was such a stunning and immediate success. The work is grounded in a number of mid-nineteenth-century intellectual currents. ${ }^{25}$ Maine inherited from scholars of German historical jurisprudence, who were reacting to the imposition of the French Napoleonic Code, a robust skepticism towards codification and towards rights founded upon natural law. In response to the utilitarian project of creating a reformed and rational Indian legal system - promoted by James Mill, Thomas Babington Macaulay, and Jeremy Bentham - he pointed to the rootedness of legal culture. For Maine, an instructor in Roman law, the loss

24 James CoOlidge Carter, Law: Its Origin, Growth, and Function 5 (1907); Lewis A. Grossman, Langdell Upside-Down: John Coolidge Carter and the AntiClassical Jurisprudence of Anti-Codification, 19 YALE J.L. \& HuMAN. 149 (2007).

For a broader examination of mid to late nineteenth-century investigations into the primitive, see ADAM KUPER, THE INVENTION OF PRIMITIVE SOCIETY: Transformations OF AN ILlUSION (1988); GEROGE W. STOCKING, JR., VictoriaN ANTHRopology (1987); and Henrika KuKLICK, The SaVAGE Within: THE Social. HISTORY OF BRITISH ANTHROPOLOGY 1885-1945 (1991). In the legal context, custom was established as an independent realm for engaging with complex social phenomena. See Kunal M. Parker, Context in History and Law: A Study of the Late Nineteenth-Century American Jurisprudence of Custom, 24 LAW \& HIST. REV. 473, 481 (2006). 
of liberty in the ancient world may have played an important role in his own search for a legalism capable of resisting the imposition of political authority.

A standard modernist dilemma animated Maine. How could law be both rooted and sustain its integrity while at the same time remain adaptive? For Maine, modern law invented a solution to the problem through legal fictions, equity, and limited legislative interventions. Primitive law itself seemed anti-Benthamite. "It is curious," wrote Maine, "that the farther we penetrate into the primitive history of thought, the farther we find ourselves from a conception of law which at all resembles a compound of the elements which Bentham determined. It is certain that, in the infancy of mankind, no sort of legislature, not even a distinct author of law, is contemplated or conceived of." ${ }^{26}$ In short, borrowing the language of Maine, primitive law provides rudimentary legal ideas — and these ideas "are to the jurist what the primary crusts of the earth are to the geologist."27

With a remarkably limited vision, Maine ignores the preliterate societies of his own time. He rejected "the slippery testimony concerning savages which is gathered from travelers' tales." ${ }^{28}$ It is particularly interesting to revisit the place where Maine sees the origins of legal primitivism, the Homeric Greeks, the legal Argonauts who carried with them across the seas fragments of norms. Tracing the earliest law to the Homeric themistes, divine judgments which regulate hospitality, the ransom of captives, and the treatment of beggars, Maine fashions primitivism as something beyond the ordinary narrative. The themistes were an epic story, paralleling the Homeric tale of travel. They told how law might migrate, be adopted by various societies along the Mediterranean fringe, create its own sense of internalized duty, shift with circumstances, and still retain a touch of its divine legalism. Themis would later appear in the Greek pantheon as the goddess of justice. But her beginnings consisted of informal social controls as a term which "visibly fluctuates between a judgment, a custom, or usage. ${ }^{29}$ Ever-gracious Phacians

26 Henry Sumner Maine, Ancient Law 4-5 (J.M. Dent \& Sons 1917) (1861).

27 Id. at 2. The role of some strands of legal primitivism in establishing continuity, promoting the valorization of common or customary law, anchoring legal traditions in firmly rooted origins, and situating formative periods of change in the distant past might all fit within what Morton Horwitz has called the conservative tradition of legal history. However, as we shall see, legal primitivism was also the source of Friedrich Engels' radical conceptions of the family. Morton J. Horwitz, The Conservative Tradition in the Writing of American Legal History, 17 AM. J. LEGAL HIST. 275 (1973).

28 HenRy Sumner Maine, Village Communities in the EAST AND WeSt 17 (London, J. Murray 1887) (1871).

29 MAINE, supra note 26 , at 2-4. 
and the rude Cyclops were all bound by some variation of the obligation to be hospitable to strangers.

Maine says something fundamental - which would be echoed by Carter. Law was essentially custom. ${ }^{30}$ Carter and Maine exemplify two principles of the legal primitivism project. First, the primitive is the counterpoint to a modern trend - through the retention of flexibility and a connection to societal norms as embodied in custom. Primitivism might either be found only in the distant past, as Maine located earlier law in a heroic age, or seen in distant points across the globe, as Carter identified simple legal systems - but it allowed an unpacking of how law was constructed through altering building blocks. Maine's jurisprudence was characterized by reasoning which began with the analysis of nonlegal materials to reach a conclusion about law. Anthropological arguments prove the inadequacies of natural law. Secondly, changing general principles suggests that despite broad shifts in the nature of society and law, we can adapt to these changes. Many of these processes are now famous. The original form of society was patriarchal; property was once held within a system of co-proprietorship; social relations shifted from status to contract; and the root of all social forms was kinship. What is most important to observe, however, is that legal primitivism provided a story much like that of Odysseus. Despite the vicissitudes of being uprooted, law was able to provide a civilizing tissue across societies. Tempests - or the vertiginous dislocations of modern market economies - could not disrupt this web of legalism. In the themistes, Maine found law's epic.

Significantly, Maine gave his Ancient Law the subtitle "Its Connection with the Early History of Society and its Relation to Modern Ideas." To a certain extent, the presence of modernism courses through works of legal primitivism. Maine, for example, countered the traditional pretensions of English judges to uncover underlying legal principles unknown to the lay public. ${ }^{31}$ But the critical aspect of primitive law for so many was its orality. John Wigmore, in his list of twenty-eight evolutionary movements of law - such as from custom to ordained law; from the simple to the complex; from the local to the universal - not surprisingly places "from the oral to the written" as the second on his list. Borrowing the old distinction in Hale and Blackstone between lex scripta and lex non scripta, primitive law was decidedly unwritten. In a sense, primitive law's fluid orality was seen as

30 In a pithy summary of this line of thinking, William Seagle, a late author in the primitivism project, writes "custom is king." WILliam SEAGLE, The Quest FOR LAW 27 (1941).

31 MAINE, supra note 26, at 31-32. 
a counterpoint to the conceptualization that was taking place in American legal science.

Late nineteenth-century jurists were caught in a web of rules. Austin and Bentham were blamed for their reified categories and for the crowding of statute books with new legislation. Owing to the creation of a treatise literature in a number of doctrinal areas - such as Williston on contract (1920) or Wigmore on evidence (1904) - and the uncovering of root principles (such as Holmes on negligence), common law as well seemed driven by an impulse to categorize and analyze in ways that denied its role as a legal folkway. Primitive law scholars responded in kind: tribal law does not recognize the divisions which are found convenient in juridical discussions. The law is one. ${ }^{32}$ The savage mind adopts a "synthetic attitude," according to one author, it "perceives resemblances more quickly and fully than it perceives differences; it apprehends and accepts wholes which we should analyze into parts in order to understand them; it unites where we should divide." ${ }^{\text {33 }}$

One recurring issue for the primitive law project's set of oppositions to modernity was whether the savage was more or less free. Contrasting the Anglo-American presumption of legal notice for complex legal regulations with a tribal society where everyone knows the law, one writer suggests that this difference exists because a member of a tribe is exposed to rules on a daily basis in his daily occupations. But there is a negative side as well. "The savage lives more in public than we do; any deviation from the ordinary mode of conduct is noted, and is visited with the reprobation of one's fellows." Limited as the savage is by his immediate surroundings, the sole lens of his action becomes a maelstrom of emotions that cannot be overcome with dispassionate analysis. Inevitably, the primitive is fear-bound, his habits hardening into superstition. ${ }^{34}$

Writing a survey of primitive law in East Africa, J.H. Driberg urges the reader to cast overboard all the usual commonplaces of European law, which "cannot be used to explain the bases of primitive legal theory." Primitive law is outlined in a series of telegraphic comments. It is more communal than modern law. It is oral, customary, and "organic." Primitive law has more duties than criminal offenses. The main purpose is to sustain a consensus or "communal equilibrium." Harm to kin is treated as harm to the

32 E. Sidney Hartland, PRimitive Law 8 (1924).

33 Id. at 138.

$34 I$ Id. at 7,79. For a Progressive Era use of legal primitivism to suggest the persistence of the folk-moot ideal of direct democracy, see CHARLES SUMNER LOBINGIER, THE PEOPLE'S LAW OR POPUlar PARTICIPATION IN LAW-MAKING FROM ANCIENT FOLK-MOOT TO MODERN REPRESENTATION (1909). 
individual. ${ }^{35}$ Such lists are a pervasive part of the legal primitivism project. These commonplaces nicely echoed the sense of primitive law as the law of the other - primitive law as the opposite of modern norms. But when it came time to actually identify examples of these rules in play, it was not always clear whether the discussion was about law or simply folkways.

Maine rendered contemporary non-Western societies invisible. But through ethnographic investigations, pseudoscientific presumptions, and the ventriloquism which a people with legal history impose upon the other, the legal primitivism project gathered anecdotal evidence outlining the difference between modern and primitive conceptions of law. Much of this evidence came from travelers, colonial administrators, and missionaries, and was subject to the peculiar filtering each observer brought to bear on their notions of the primitive. Among the Bantu of South Africa, it was said, a man must never sleep on the right-hand side of the bed which he occupies with one of his wives. For if he should break the rule and touch her with his right hand, he would lose his strength in war and surely be slain. ${ }^{36}$ This law has some deep underlying psychological logic: sexual prowess and warrior prowess do not mix. But for American legalists of the Victorian era it posed a conundrum. Was this a law or merely a custom - and is there a difference? The nub of the difficulty for late nineteenth-century and early twentieth-century Anglo-American legalists was the absence of an official framework for punishment. The sanction was a consequence of the offense, not the result of compulsion.

Unlike American legalism, where law functioned by providing an official apparatus for coercion in order to safeguard citizens, creating the means for private ordering of affairs such as contracts or employment relations, or served to settle disputes, primitive law was often portrayed prior to Malinowski's work as norms which exist in their own right. In short, the Bantu taboo had the weight of a command, but with neither an authorial persona nor official enforcement behind it - nor even a rational basis. Perhaps unable to move beyond Austinian intransigence or the particular provincialism of modern Anglo-American legal thinking, which vests all law-creating powers in either an assertive legislature or an assertive judiciary, Victorian era legalists simply should have ignored the manifold exceptions of primitive law. In a sense, they could have been like Gulliver's Houyhnhnms who could not bring themselves to say "the thing which is not." But, of 
course, such a fascination with otherness is precisely what has been critical to the modernist enterprise.

Within the primitive law project, therefore, there existed two approaches pointing in opposite directions. One focused on excavating the commonalities present in all primitive legal systems. These were often negations of modernism - such as status not contract, communal ownership of property not individual possession, vengeance not an instrumental criminal law founded upon principles of deterrence. The other approach created an archipelago of different archaic customary laws with different legal rituals and varied notions of justice. In the words of Guy Carleton Lee, "of system there was little, of scientific arrangement still less. The customs, and later laws, appear as if heaped one upon another in inextricable confusion." ${ }^{37}$ These varieties of primitive legal experience might be seen in the omnibus Evolution of Law series published as a trilogy in 1918. It reads like a virtual tour of the British Museum: a quick treatment of Babylonian contracts, Hebrew kinship relations, and (in lieu of the Elgin Marbles) more than a touch of the Glory-that-was-Greece, the Grandeur-that-was Rome. The order of the museum salons has an elusive underlying logic. In the primitive law literature, Native Americans (exemplar of nomadic primitivism) rub shoulders with the Law of Manu (exemplar of Aryan law). ${ }^{38}$

The choice of primitive law depends upon the root anxieties of the writer. Henry Adams, for example, celebrated Teutonic forests as the birthplace of republican constitutionalism with the same romantic, antimodernist impulse which gave rise to a late nineteenth-century rage in gothic architecture. Not infrequently, charts and graphs show the parallel development of legal systems sharply divided by time and space, and there is a whiff of pseudoscience, orientalism, and a discomforting number of racial assumptions. Sometimes the mid-level generalization does not hold. Liberal provisions for divorce served as a characteristic feature of all archaic legal systems, an American judge investigator of legal primitivism tells us. But immediately he adds an exception: in Rome, to its credit, divorce was wholly unknown for five hundred years. ${ }^{39}$

The anecdotal preoccupation with the legal status of women is striking. Women in Arabia, it was claimed, would dismiss their husbands at will by turning around the opening of the tent "so that if the door had faced

37 LEE, supra note 8 , at 1 .

38 Id. at $4-5$.

39 M.F. MORRIS, THE HiSTORY OF THE DEVELOPMENT OF LAW 34-35 (1909). 
east, it now faced west, and when the man saw this he knew that he was dismissed and did not enter." ${ }^{40}$ In the Mariana Islands, if a man was found guilty of adultery, the women of the neighborhood destroyed his house and all his visible property. ${ }^{41}$ Among the Awemba, inheritance rules required the removal of death from the body of a predecessor's wife, or wives, through anointing with oil before the heir might come into the deceased's property. Taking the stigma of death away from a chief's wife and property required his successor to have sexual intercourse with the departed chief's widow(s) ${ }^{42}$ Persons taking wives and property would be admonished to good behavior. By the time Tyler wrote his Ancient Law with nearly the same title as Maine's magnum opus, the interpretation of the primitive family had shifted from patriarchal to matriarchal structures. Indeed, the American writer, Lewis Henry Morgan, added one more wrinkle to this scheme. A primeval matriarchal structure was replaced by a patriarchal family as an institution designed to ensure the transgenerational transmission of private property to male heirs. ${ }^{43}$

But it was not only this newfound female status which made primitivism an alter ego or, perhaps, an alter-id for Victorian Anglo-America. Through the looking-glass of modernism, legal primitivism posed the antithesis of contemporary social norms such as private property and the monogamous family. The promiscuous exchange of goods and women, or their protection, signaled the core elements of a legal system. McLennan, who argued that large-scale female infanticide placed women in short supply and therefore they were circulated as sexual objects among the men of the tribe, called this "rude polyandry," which he labeled as "depraved." ${ }^{44}$ According to one writer,

40 William Robertson Smith, Kinship and MarRiage in Early ARabia 65 (Cambridge, Cambridge Univ. Press 1885).

41 William I. Thomas, The Relation of Sex to Primitive Social Control, 3 AM. J. SoC. 754,765 (1898).

42 The Native Tribes of North-Eastern Rhodesia: Their Laws and Customs 9 (John Charles Codrington Coxhead ed., 1914).

43 MoRGAN, supra note 7, at 345. Morgan's interconnections between property and social organization have been particularly influential for Marxist thought since their use in Friedrich ENGELS, ORIGIN OF THE FAMILY, PRIVATE PROPERTY, AND THE STATE (1884). Marx wrote extensive reading notes on Morgan's Ancient Society. William H. Shaw, Marx and Morgan, 23 HIST. \& THEORY 215 (1984); Donald R. Kelley, The Science of Anthropology: An Essay on the Very Old Marx, 46 J. HIST. IDEAS 245, 245 (1984). On Morgan as the founder of cultural anthropology, see Thomas R. TRautmanN, Lewis HenRy Morgan and the INVENTION OF KinshiP (1987); CARL RESEK, LEWIS HENRY MORGAN: AMERICAN SCHOLAR (1960); and BERNARD J. STERN, LEWIS HENRY MORGaN: SOCIAL Evolutionist (1931). JOHN MCLENNAN, STUdIES IN ANCIENT HistoRy 138 (London, MacMillan new ed. 
uncivilized societies live in "a primitive communistic state of the sexes." 45 Writing in response to Emile de Laveleye's work on primitive property, $D e$ law proriété et de ses formes primitives, T.E. Cliffe Leslie sees joint ownership as the usual form of property. The first form of property is chattel, not land, and it is held largely in common. For a moment, Leslie appears to be attracted to such shared property rights, while trying to distinguish modern-day communism from the primitive form. What stops him from a return to communal ownership in property is an image - perhaps both tempting and disturbing - "why not also communism in women?"46

As much as legal primitivism was a Victorian project, it was also a modernist enterprise. Looking at the different appropriations of legal primitivism by two leading late nineteenth- and early twentieth-century figures with undeniable modernist, even pragmatic, pedigrees, Oliver Wendell Holmes, Jr. and John Dewey, we can see the modernist ambivalence about the connection to the archaic past. Holmes exemplifies one approach to excavating legal primitivism - the idea that by locating the savage or rude beginnings of legal rules we might liberate ourselves from their grasp. As a modernist, Holmes sifted through the bramble of received common law, establishing abstract principles and drawing connections between legal doctrine and coherent responses to social needs.

Yet in 1876 Holmes participated in the legal primitivism project by writing an essay entitled "Primitive Notions in Modern Law," where he traced the origins of tort law. Holmes criticized the odd assortment of contemporary liability principles, "a medley of rules gathered from the four corners of the law," each disconnected from the other, but sharing the primitive idea of surrendering the wronging object. Liability in primitive societies attaches directly to the thing that does the damage. This comes from the

1886); JOHN MCLENNAN, PRIMITIVE MARRIAGE: AN INQUIRY INTO THE ORIGIN OF THE ForM OF CAPTURE IN MARRIAGE CEREMONIES 11, 90-95 (Edinburgh, A \& C Black 1865). G. Stailand Wake, The Primitive Human Horde, 17 J. ANTHROPOLOGICAL INST. GR. BRIT. \& IR. 276, 276 (1888) identifies marriage structure as an indicator of primitivism. On the sexual politics of primitivism, see Elizabeth Fee, The Sexual Politics of Victorian Social Anthropology, 1 FEMINIST STUD. 23 (1973). More generally, on the underside of late nineteenth-century sexuality, see CAROLL SMITH-Rosenberg, Disorderly CONDUCT: Visions OF GENDER IN Victorian AMERICA (1986).

45 Charles Franklin Thwing \& Carrie F. Butler Thwing, The Family: An HistoriCAL AND SOCIAL STUDY 10-16 (Lothrop, Lee \& Shepard rev. \& enl. ed. 1913).

46 T.E. Cliffe Leslie, Preface to Emile De Laveleye, Primitive Property, at xix (London, MacMillan 1878). 
naive idea of the animation of all nature - such as can be seen in the childish beating of the inanimate object that wounds. "The personification of even inanimate objects ... finds its explanation in passion, not in self-interest. ${ }^{147}$ Indeed, Holmes explained almost every doctrinal area of law - torts, property, criminal law (imagine the focus on savage vengeance), family law, and procedure - through a binary set of lenses, modern and primitive. The origin of modern property was primitive communal property. For Holmes, primitive law was the infancy of modern common law, and the time had come for this law to put aside its childish ways.

No less of a modernist bedfellow than John Dewey read Holmes' essay with a very different mindset than Holmes himself. "Going back in history," Dewey observed, "is like going from the mouths of rivers now far separate, as separate as the Pacific Ocean from the Gulf of Mexico, to a common watershed." This original law, founded in "the crude psychological structure of primitive man," provides continuity for Dewey. "Every new institution is, like the organ of an animal, an old one modified. Continuity is never broken; the old is never annihilated at a stroke, the new never a creation ab initio." Inherited norms from these primitive beginnings must be functional, and adapted to new conditions. However, within them are embedded fundamental psychological truths. ${ }^{48}$ Primitivism is the usable un-past.

We see in these two illustrations a Janus-faced approach to legal primitivism. Primitivism is the category where old doctrines - archaic, irrational, rooted in atavistic psychology - are discarded. It is a kind of cabining of the past, as Holmes sifts legal history to determine what legal doctrinal remnants should survive. For Dewey, the other apostle of modernism, primitivism defines what is truly human. It is the locus of eternal psychological verities, a reminder of the distinct aspects of the

47 Oliver Wendell Holmes, Jr., Primitive Notions in Modern Law (pt. 1), 10 AM. L. REV. 422 (1876), reprinted in THE FoRMATIVE EsSAYS OF JUSTICE HOLMES: THE MAKING OF AN AMERICAN Legal PHILOSOPHY 129 (Frederic Rogers Kellogg ed., 1984). Holmes' conception is clearly influenced by EDWARD B. TYLOR, PRIMITIVE CULTURE (J.P. Putnam's Sons 6th ed. 1920) (1871), where it is argued that animism, the anthropomorphic notion that inanimate objects have some of the qualities of living beings, is central to primitive cosmological conceptions. Holmes would continue his research into primitive law by examining the underlying connection between land transfer and the vesting of personal rights upon another. Oliver Wendell Holmes, Jr., Primitive Notions in Modern Law (pt. 2), 11 AM. L. REV. 641 (1877). See G. EdWard White, Justice Oliver Wendell Holmes: LaW and the INNER SELF 131-34 (1993).

484 JOHN DEWEY, Anthropology and Law in John Dewey, in THE EARLY WORKS OF JOHN DEWEY 1882-1894, at 37 (Jo Ann Boydston ed., 1971). 
human condition embedded in legal norms which will always remain with us. The very different approaches to legal primitivism seen in the writings of Holmes and Dewey should remind us that, above all, legal primitivism is an ambiguous appropriation. Legal primitivism had so many meanings. It provided a step on an evolutionary ladder, a point of contrast to how we see the uncivilized - often colonial - other, an archeology of knowledge, a wellspring of possibilities, an $u r$-law, a liberating counterpoint to doctrinal formalism, an exotic interlude, or a laboratory to experiment with socio-legal notions of the origins of rules - all this, and more.

\section{The Primitive Beginnings of Legal Realism}

Maine's Ancient Law was published only two years after Darwin's The Origin of Species. Nevertheless, Maine's work seems static, and mildly evolutionary at best. He saw primitive law as an essentially stagnant cultural milieu which was difficult to change. ${ }^{49}$ Yet the development of legal primitivism after Maine created ballast for the emergence of a strong current of evolutionary thinking on the subject. While legal primitivism was partly a response to the closely ordered systems of codification and systematization, of Austinian and Benthamite orthodoxies, its own mental storehouse increasingly seemed too chaotic. Scattered fragments of ethnographic anecdote and historical speculation demanded a broader synthetic conceptual framework. Moreover, the anxieties surrounding the role of women prompted a stronger role for evolutionary thinking. Surely, the absence of mechanisms of sexual control as Victorians knew them - marital fidelity, monogamy, traditional restraints on consanguineous marriages, and even a rude form of the cult of domesticity - suggested that law was not fixed. The dilemma of unfettered sexuality, however, suggested that progress might be seen in the movement from primitive "depravity," a term used by Morgan, to civilized eros.

Legal primitivism found itself with the old Cheshire cat problem. One form of legalism slowly disappeared, and another took its place. Does that mean there was a causal connection? A form of evolution? The turn towards ethnographic information - with all its complexity and detail - and simple evolutionary arguments did not fit well together. Progress was simply not that linear. Those few scholars who have examined the writings of legal primitivism have mistakenly identified this literature solely with Darwinism as a species of evolutionary jurisprudence. ${ }^{50}$ Such a set

49 Brian Smith, Maine's Concept of Progress, 24 J. HiST. IDEAS 404, 407-08 (1963).

50 James E. HERGET, AMERICAN JuRISPRUdENCE 1870-1970: A History 117-46 
of lenses is certainly useful: it contextualizes legal thinking within a broader historical-cultural framework, connects these works to earlier eighteenthcentury evolutionary models, and fully recognizes the immense impact of Darwin on Anglo-American jurisprudential thinking. ${ }^{51}$ On the other hand, focusing upon legal evolution - posing the question "how does law change?" - ignores the question so often asked in this ethnographic literature: "how is primitive law different?" To understand this difference, one only has to examine the range of concerns animating the primitive law project: the search for the roots of popular sovereignty in customary law, the debate about the German idealist equation of custom with national will (echoes of Friedrich Karl von Savigny's Volksgeist) versus law shaped through social necessity, the reaction against Austinian notions of law as a positive command, and the question whether common law is a legal folkway.

Here lie the ambiguities of primitive law. On one hand, primitive law was always evolving. There is a series of evolutionary arcs: mitigation of criminal law is proof of a civilizing process, as is the shift from capture to legal rituals as a formalization of marriage. But in this Whiggish great chain of being, modern law was the paradigm and primitive law always the baseline. In the words of Lewis Morgan's 1873 three-stage theory of law, social and legal systems move from savagery, to barbarism, to civilization. In the words of Paul Vinogradoff's theory of the 1920's, from totemistic law to tribal law to civic law. On the other hand, there is a countervailing trend valorizing unwritten custom. One strand of this trend - with a long Anglo-American political tradition - identifies custom with law based upon popular sovereignty rather than the command of a sovereign. ${ }^{52} \mathrm{~A}$ different strand, less popular in Anglo-American circles, follows nineteenth-century German Romantic idealism and identifies law with the national will. And still another strand, with roots in seventeenth-century debates, sees custom as a vindication of local legal cultural norms.

The search for a structured, ordered, and - almost by definition evolutionary law reached its pinnacle with John Henry Wigmore. Wigmore associated law with "uniformity." Yet legal primitivism had increasingly become a thicket of variations with, in his words, an "immense variety and variation of forces." While the evolution of marriage, for example,

(1990); Herbert Hovenkamp, Evolutionary Models in Jurisprudence, 64 TEx. L. REV. 645 (1985). By focusing on the Darwinian aspects of the legal primitivism literature, these works have ignored much of the larger genre. See also E. Donald Elliot, The Evolutionary Tradition in Jurisprudence, 85 COLUM. L. REV. 38 (1985). PETER STEIN, Legal EVOlution: The STORY OF AN IDEA 122-29 (1980).

52 See, e.g., HENRY SCOTT, THE Evolution OF LAW: A HistoriCAL REVIEW 39 (1908). 
was supposed to follow the pattern of developing from promiscuity through polygamy to monogamy, outside factors could influence the choice of one form of sexual union over another. Wigmore urged the replacement of the notion of progress in evolution with "movement." The problem was that so many factors at the horizontal level, such as other societies and environmental pressures, were being ignored, and the focus invariably centered upon vertical advancement to the current day. With its gravitational tugs, Wigmore called his theory the "planetary system" of law's evolution. However, Wigmore was unwilling, perhaps unable, to shift fully away from the set of binaries between primitive and modern that Maine had set into motion. Listing twenty-eight of these general trends - including from oral to written law, from local to general law, from theocratic to secular law, from criminal to civil law, from rights in rem to rights in persona, from family to individual rights, from ethnic to territorial law, from immovable to movable property - Wigmore pointed out the lack of constancy in their application. Nevertheless, with all its causal complexity, Wigmore's planetary system simply sought to link a series of deeply situated external pressures with abstract notions of how law might change. Not surprisingly, then, Wigmore's planetary system was as full of epicycles as that of any good pre-Copernican astronomer. ${ }^{53}$

Bronislaw Malinowski begins his Crime and Custom in Savage Society by complaining of too much research in the field. The study of primitive law "was driven into an impasse of artificial and sterile constructions." ${ }^{4}$ Indeed, Maine's recovery of customary law, Morgan's dalliance with the erotic, and Wigmore's complex planetary evolutionary schema seemed like an elaborate house of cards constructed out of "hearsay anthropology." 55 Malinowksi insisted that all understandings of primitivism must be founded upon rigorous fieldwork. More importantly, Malinowski redefined legalism itself. It was not a "homogeneous, perfect body of rules, based upon one principle developed into a consistent system," but a set of contradictions, the balancing of norms and violations, and the inherently situational imposition of laws. ${ }^{56}$

Malinowski greeted Karl Llewellyn's and E. Adamson Hoebel's 1941

John Henry Wigmore, Problems of the Law's Evolution, 4 VA. L. REV. 247 (1917), reprinted in JOHN HENRY WIGMORE, PROBLEMS OF LAW: ITS PAST, PRESENT, AND FUTURE 1 (1920). Bronislaw Malinowski, Crime and CuStom IN SaVAGe Society 1-5 (1926). Id. at 121 . Id. at 100 . 
publication of The Cheyenne Way with enthusiasm. ${ }^{57}$ In a marked departure from earlier studies of primitive law, however, these two authors, a Columbia Law School professor and an anthropologist, developed a case-method to replace conclusory ethnographic descriptions. Law is treated as a distinct category, which is separate from mores, taboos, and other cultural obligations. While Llewellyn and Hoebel romanticized Cheyenne law, "the curious and lovely Cheyenne material," as the authors called their sources, at the same time, however, the failures of Cheyenne law - the smoldering of minor grievances, its inability to craft settlements in the face of necessity made Llewellyn, especially, more accepting of the imperfections of legal modernism. ${ }^{58}$ Llewellyn and Hoebel used Cheyenne legalism to address two preoccupations of the legal realists: first, since there were no formal law codes to be adjudicated before official courts and enforced by a constabulary, to look at law in action rather than law on the books; and, secondly, to break down the bedeviling is/ought distinction. ${ }^{59}$ Hoebel called primitive law the "henchman of legal realism." 60

Malinowski's reading of The Cheyenne Way may be used as a kind of thick description in participant-observer style. In other words, in order to understand Llewellyn's and Hoebel's analysis as the penultimate major contribution of the legal primitivism project, we should use Malinowski's lengthy review of the book, which was published in The Yale Law Journal, in order to see Malinowski seeing Llewellyn and Hoebel seeing Cheyenne legal process at work. According to Malinowski, Llewellyn and Hoebel, in

57 Bronislaw Malinowski, A New Instrument for the Interpretation of Law - Especially the Primitive, 51 YALE L.J. 1236 (1942).

58 Karl Llewellyn \& E. Adamson Hoebel, The Cheyenne Way: Conflict and CASE LAW IN PRIMITIVE JURISPRUdENCE 289, 339-40 (1941); see William TWINING, KARL LLEWELLYN AND THE REALIST MOVEMENT 153-69 (1973).

59 N.E.H. Hull, RosCoE POUND AND Karl Llewellyn: SEARCHING FOR AN AMERICAN JURISPRUDENCE (1997); Malinowski, supra note 57, at 1238. By contrast, others saw the rules of archaic law as being "in the highest degree formal." See Roscoe Pound, The End of Law as Developed in Legal Rules and Doctrines, 27 HARV. L. REV. 195, 198 (1914).

60 E. Adamson HoEbel, The Political Organization and LaW-Ways of the ComANCHE INDIANS 48 (Memoirs of the Am. Anthropological Ass'n No. 54, 1940). See William L. Twining, Two Works of Karl Llewellyn (pt. 2), 31 MoD. L. REV. 161, 167 (1968). Assaf Likhovski has argued that those advocating the study of informal law often emerged from the periphery of legal systems. Assaf Likhovski, Czernowitz, Lincoln, Jerusalem, and the Comparative History of American Jurisprudence, 4 THEORETICAL INQUIRIES L. 621 (2003). I have tried to show that the periphery itself, in the form of the primitive landscape, may be a cultural construction for the sake of examining law in action. 
the tradition of legal primitivism, missed the dynamism of Cheyenne law by failing to address how Native Americans "have been long subjected to the process of detribalization, to new environmental settings, to changing economic systems, and undoubtedly also to the influence of the white man's legal and political pressure."61 There were no longer any pure laboratories for the primitivist project, and therefore The Cheyenne Way must be seen as the construction of a parallel world, a legal other, envisioned for heuristic and instrumental purposes as a counterpoint to modern law, and therefore a classic move in the creation of the binary juxtaposition of primitive and modern.

Malinowski does not reject this parsing of the legal world, but reconstructs it through ethnographic lenses. Primitives are concerned primarily with the mastery of their physical environment. "The fundamental rules of marriage and kinship, of property, inheritance, and succession, of co-operation or agreement, are as indispensable to the effective success of an activity as the tolls used, the food consumed, the participants who work, and the values which guide them." ${ }^{162}$ But for moderns, "law is part of social and cultural engineering," and critical for enterprises such as creating planned economies, planned politics, and planned cultural regimes. ${ }^{63}$ Within this argument lies the denouement of the legal primitivism enterprise. Anthropologists would embark upon field research to uncover the relationship between law, social organization, and the functional needs of the community - an essentially descriptive project; legal realists, as their ideas became increasingly accepted, might focus their energies on remaking law in the image of objective social goals - where knowledge of regulatory mechanisms in a modern society was the key to success.

When Maine turned to legal primitivism, he found an unclaimed territory, a terra nullius inhabited by only a small number of norms. Over the course of time, however, the parallel landscape of primitive law was colonized to such an extent that it became crowded with all sorts of rules, binary distinctions with modernism such as the twenty-eight listed by Wigmore, and evolutionary principles; it was becoming as unpleasant a place for jurisprudential speculation as the old world of common-law formalism. It would be simple to add yet another binary juxtaposition with a dash of evolutionary thinking, and speak of a progression from pseudoscience to modern anthropology when describing the contributions of Malinowski,

61 Malinowski, supra note 57, at 1237.

62 Id. at 1246.

63 Id. at 1247. 
Llewellyn, and Hoebel. But Llewellyn and Hoebel, the last important American legal primitivists, created their own mirror-law. Although there were clearly encounters with the broader early twentieth-century American economy and law, they treated the Cheyenne as a world apart. Seeing the law as other was simply too attractive a mental construct for them to abandon. ${ }^{64}$

\section{LOOKING FOR THE LEGAL OTHER}

This essay has suggested that legal primitivism became the repository of everything that legal modernism cast off - what was disturbing, what was vestigial, and even what was feared might be lost (like customary law), and what ultimately might be recovered. The legal primitivism project emerged out of the thicket of formalism as a repository for customary law. Notions of legal development allowed for historicist, sometimes even challenging readings of earlier forms of legalism. However, savage law was also, sometimes but not always, a form of nomos to be superseded and repudiated. In the first few decades of the twentieth century, proto-legal realists and legal realists, like Llewellyn, continued the investigations into primitive law, where law in action trumped law on the books. Yet legal realists found their own legal other. Ironically, it turned out to be formalism. Writing a triumphalist narrative, which we continue today, legal realists juxtaposed themselves to the parallel world of formal legal thinking - and the primitivism project became a vestigial, half-forgotten relic of an earlier age.

The invention of legal primitivism was an act of imagination. Karl Llewellyn described his rendering of the savage with a marvelous metaphor, a play on Holmes' famous image of law as a magic mirror in which society is reflected. Law "is a world like Alice's Looking-Glass - both difficult to break into, and difficult, once one has become acclimated to it, to break out of. "65 Legal primitivism reflects a need for something which is not official law, not our ordinary society - where one can be transported away from habits of mind. Legal primitivism imported into a parallel world, a wonderland, norms from distant times and faraway places. A kind of legerdemain occurred where Anglo-American law, slowly built upon a layered edifice of statutes and judicial decisions, had to confront the exotic. In this regard, legal primitivism

64 Ajay K. Mehrotra, Law and the "Other": Karl N. Llewellyn, Cultural Anthropology and the Legacy of The Cheyenne Way, 26 LAW \& SOC. INQUIRY 741 (2001).

65 LLEWELLYN \& HOEBEL, supra note 58, at 41. 
falls squarely within the paradigm of legal transplants, insofar as it reflects imported legal science. ${ }^{66}$

Most discussions of legal transplants, however, rely upon a remarkably botanical turn of phrase. Law is transferred from one place to another it takes seed, is grounded in the needs of another society and, perhaps, even grafted to existing legal norms, and ultimately becomes either a successful transplant or withers away. One can almost conjure up the image of Captain William Bligh's ill-fated mission to transport breadfruit trees from the South Pacific to the West Indies. Legal transplants are part of a system of international exchange. Legal primitivism, however, challenges this straightforward model of encounters. It was closer to the mounted specimen of an exotic species than a living plant. It was a pastiche of legal materials imported for the very purpose of cabining, setting aside, and distinguishing from contemporary law. In a sense, a more apt metaphor might be the legal Wunderkammer, filled with all sorts of curiosities which might startle and inform - and perhaps even be useful.

Legal primitivism is not unusual in this regard. Law might very well need a law of the other to define itself. Indeed, even earlier forms of Anglo-American legal thinking had positioned the American system in opposition to other legal systems. Blackstone's common law was juxtaposed with its antithesis, continental civil law. Early American republican law, as seen in the works of James Wilson and Chancellor Kent, was defined in contrast to an English legal tradition created in the shadow of monarchic and aristocratic pretensions. The law of the non-slave states, and their ideological emphasis upon freedom of contract, was juxtaposed to the legalism embedded in Southern slavery. In the age of the Cold War, when the Soviet Union conveniently presented counter-models of collectivism and godlessness, centralization and limitations on liberal notions of civil rights, Americans found their foil in socialist legalism. ${ }^{67}$

66 On this literature, see David Nelken, Toward a Sociology of Legal Adaptation, in Adapting Legal Cultures 7 (David Nelken \& Johannes Feet eds., 2001); Michele Graziadei, Transplantations and Receptions, in THE OXFORD HANDBOOK OF COMPARATIVE LAW 441 (Mathias Reimann \& Reinhard Zimmerman eds., 2006). On the idea of different types of transplants, see Jonathan M. Miller, A Typology of Legal Transplants: Using Sociology, Legal History, and Argentine Examples to Explain the Transplant Processes, 51 AM. J. CoMP. L. 839 (2003). Ron Harris, The Transplantation of the Legal Discourse on Corporate Personality Theories: From German Codification to British Political Pluralism and American Big Business, 63 WASH. \& LEE L. REV. 1421 (2006) shows how legal transplantation involves not only the importation of fixed rules, but also legal conflicts and debates.

67 For discussions of these historical examples, see on republicanism, Steven Wilf, 
But who is our legal other now? And can we make do without one? The converging of law across the globe and the emergence of institutions dedicated to international harmonization, our persistent preoccupation with the present, and the accentuation of the functional aspects of statutes, may threaten the very notion of resurfacing parallel worlds of legalism. Modern legalism was crafted in an age of anxiety, and legal primitivism was a way of buffering its tensions. Yet is not all legalism - for norm-making is a fragile business - fraught with anxiety?

The First Republican Revival: Virtue, Judging, and Rhetoric in the Early Republic, 32 CONN. L. REV. 1675 (2000); on freedom and slavery, AMY DRU STANLEY, From Bondage to CONTRACT: WaGe Labor, MarRiage, AND the MarKeT in AN AGE OF SLAVE EMANCIPATION (1998); on the Cold War's influence on American law, MARY L. DUDZIAK, COLD WAR CIVIL RIGHTS: RACE AND THE IMAGE OF AMERICAN DEMOCRACY (2002). 
